\title{
Edukasi Penggunaan Hand Sanitizer Dan Cairan Desinfektan Untuk Pencegahan Penyebaran Covid-19 Di Wilayah Desa Talia Kecamatan Abeli Kota Kendari
}

\author{
Wa Ode Yuliastri, La Ode Muhammad Andi Zulbayu, Muhammad Isrul, Silviana \\ Hasanuddin, Nikeherpianti lolok \\ Program Studi Farmasi, Universitas Mandala Waluya
}

\begin{abstract}
ABSTRAK
Penyebaran Covid-19 di Indonesia masih menjadi perhatian khusus bagi Pemerintah Pusat, Pemerintah Daerah maupun masyarakat. Belum tersedianya obat maupun vaksin dalam hal mencegah dan mengobati infeksi Covid19 ini memberikan dampak yang besar terhadap social maupun ekonomi masyarakat. Salah satu yang menjadi sorotan adalah ketersediaan hand sanitizer dan cairan desinfektan yang sangat langka dan harganya sangat melambung tinggi terutama di Kota Kendari. Salah satu daerah tujuan dilakukan edukasi terkait pembuatan dan penggunaan hand sanitizer dan cairan desinfektan adalah Kelurahan Talia Kecamatan Abeli Kota Kendari. Tujuan dari kegiatan ini adalah untuk melakukan edukasi kepada masyarakat Kelurahan Talia tentang penggunaan hand sanitizer dan desinfektan untuk mencegah penyebaran Covid-19. Metode pelaksanaan kegiatan pengabdian ini dilakukan dengan membuat sebuah video edukasi tentang cara pembuatan dan penggunaan sediaan hand sanitizer dan cairan desinfektan yang benar dan tepat sasaran. Hasil dari kegiatan ini adalah meningkatnya pemahaman masyarakat tentang pembuatan dan penggunaan hand sanitizer dan desinfektan. Hal ini berdasarkan masyarakat yang aktif dan antusias dalam memberikan pertanyaan untuk mengetahui langkah-langkah pencegahan penyebaran virus Covid-19.
\end{abstract}

Kata Kunci : Covid-19, hand sanitizer, desinfektan, Kelurahan Talia

\section{Education on the Use of Hand Sanitizers and Disinfectants to Prevent the Spread of Covid-19 in the Talia Village, Abeli District, Kendari City}

\section{ABSTRACT}

The spread of Covid-19 in Indonesia still became the main concern for the Central Government, Regional Government and the community. The unavailability of drugs or vaccines in terms of preventing and treating Covid-19 infection has had a major impact on the social and economy of the community. One of the highlights is the availability of hand sanitizers and disinfectants which are very rare and the prices are very high, especially in Kendari City. One of the areas for education related to the production and use of hand sanitizers and disinfectants is Talia Village, Abeli District, Kendari City. The purpose of this activity was to educate the people of Talia Village about the use of hand sanitizers and disinfectants to prevent the spread of Covid-19. The method of implementing this service activity was carried out by making an educational video on how to make and use the correct and right target hand sanitizer and disinfectant preparations. The result of this activity ws an increased understanding of the community about the manufacture and use of hand sanitizers and disinfectants. This was based on people who are active and enthusiastic in asking questions to find out how to prevent the spread of the Covid-19 virus.

Keywords: Covid-19, hand sanitizer, disinfectant, Talia Village

\section{Penulis Korespondensi :}

Wa Ode Yuliastri

Program Studi Farmasi, Universitas Mandala Waluya

E-mail : waodeyuliastri@yahoo.com

No. Hp : 085341501782 


\section{PENDAHULUAN}

Pada akhir tahun 2019 hingga awal tahun 2020 dunia mengalami kejadian luar biasa terutama di bidang kesehatan, yaitu berupa pandemi virus yang menyerang secara global. Virus ini diperkirakan muncul pertama kali di Cina tepatnya di kota Wuhan dan diduga berasal dari pasar ikan dan hewan yang ada di daerah tersebut. Pada awal kemunculannya, WHO menamakan sementara sebagai 2019 novel coronavirus (2019-nCoV), kemudian pada tanggal 11 Februari 2020 WHO mengumumkan nama baru yaitu Coronavirus Disease (COVID-19) yang disebabkan oleh virus Severe Acute Respiratory Syndrome Coronavirus-2 (SARS-CoV-2) (Susilo, dkk.,2019).

Indonesia masih bergelut melawan virus Corona hingga saat ini, sama dengan negara lain di dunia. Jumlah kasus virus Corona terus bertambah dengan beberapa melaporkan kesembuhan, tapi tak sedikit yang meninggal. Usaha penanganan dan pencegahan terus dilakukan demi melawan Covid-19 dengan gejala mirip flu. Upaya untuk mencegah penyebaran virus termasuk pembatasan perjalanan, karantina, pemberlakuan jam malam, penundaan dan pembatalan acara, serta penutupan fasilitas (Fadli, 2020).

Pencegahan dilakukan oleh pemerintah pusat, maupun daerah. Mulai dari pembatasan jarak antara individu (social distancing) sampai karantina wilayah (lock down) (Juaningsih dkk.,2020). Dalam upaya pencegahan tersebut, masyarakat juga mengambil peran dalam hal perilaku hidup sehat dan bersih (PHBS) maupun penggunaan hand sanitizer sampai penyemprotan cairan desinfektan. Namun dalam aplikasinya, pemahaman masyarakat tentang pembuatan, penggunaan handsanitizer dan cairan desinfektan masih kurang tepat sehingga dapat menimbulkan sesuatu yang tidak diinginkan seperti terjadinya resistensi terhadap virus dan bakteri akibat penggunaan yang tidak tepat bahkan sampai dapat memicu munculnya penyakit baru pada masyarakat (Astuti dkk.,2020).

Masyarakat di Kota Kendari secara umum, khususnya di desa Talia Kecataman Abeli memiliki keresahan yang tinggi terhadap penyebaran Covid19. Hal ini menyebabkan permintaan terhadap hand sanitizer dan cairan desinfektan oleh masyarakat meningkat tajam. Namun pemahaman dan pengetahuan masyarakat dalam menggunakan hand sanitizer dan cairan desinfektan tersebut masih sangat minim, sehingga dikhawatirkan dapat menyebabkan resistensi serta menyebabkan iritasi kulit pada manusia bahkan bisa menimbulkan penyakit yang lebih berbahaya. Kelangkaan hand sanitizer yang terjadi di Kota Kendari menyebabkan sebagian besar masyarakat membuat secara mandiri, namun hal ini tentunya tidak sesuai dengan standar yang ditetapkan oleh WHO (World Health Organization). Maka dipandang perlu untuk dilakukan edukasi terhadap masyarakat dalam hal pembuatan dan penggunaan hand sanitizer dan cairan desinfektan tersebut. 
Secara garis besar bagian pendahuluan memuat latar belakang, perumusan masalah, tujuan kegiatan, dan kajian literatur. Penulis dituntut mengemukakan secara kuantitatif potret, profil, dan kondisi khalayak sasaran yang dilibatkan dalam kegiatan pengabdian kepada masyarakat. Dapat digambarkan pula kondisi dan potensi wilayah dari segi fisik, sosial, ekonomi, maupun lingkungan yang relevan dengan kegiatan yang dilakukan. Paparkan pula potensi yang dijadikan sebagai bahan kegiatan pengabdian kepada masyarakat. Penulis diminta merumuskan masalah secara konkrit dan jelas pada bagian ini. Jelaskan tujuan yang hendak dicapai pada kegiatan pengabdian.

\section{METODE}

\section{Pelaksanaan Pengabdian}

Masyarakat dilaksanakan pada bulan November 2020 dikantor desa Talia . Pengabdian diawali dengan pembuatan video cara pembuatan hand sanitizer berdasarkan panduan WHO dan cara pembuatan cairan desinfektan sesuai dengan anjuran BPOM. Video tersebut kemudian dipersentasekan dan didiskusikan kepada peserta pengabdian yang merupakan warga Desa Talia. Video tersebut juga dibagi-bagikan dalam media flash disk kepada warga dan aparatur desa Talia.

\section{HASIL DAN PEMBAHASAN}

Penggunaan hand sanitizer merupakan kebiasaan normal baru atau new normal yang perlu diterapkan oleh masyarakat. Penggunaan hand sanitizer oleh masyarakat kelurahan Talia semakin meningkat dengan tingkat kesadaran akan pentingnya pencegahan penyebaran virus Covid-19. Namun terdapat beberapa masalah tentang hand sanitizer dan desinfektan yang perlu diketahui oleh masyarakat kelurahan Talia diantaranya yaitu bagaimana cara pembuatan sendiri hand sanitizer dan desinfektan serta bagaimana cara penggunaannya yang benar dan tepat sasaran.

Tujuan kegiatan pengabdian masyarakat ini dilaksanakan adalah untuk memberikan edukasi kepada masyarakat kelurahan Talia tentang cara pembuatan hand sanitizer dan desinfektan serta cara penggunaan yang benar. Kegiatan pengabdian ini dilakukan pada bulan November 2020 bertempat di balai kelurahan Talia. Peserta yang terlibat dalam kegiatan ini adalah masyarakat kelurahan Talia yang diwakili oleh ketua RT dari beberapa lingkungan di kelurahan Talia. Pemilihan lokasi ini didasarkan pada kondisi wilayah yang strategis sebagai wilayah ekowisata, sehingga memungkinkan mobilitas serta aktivitas masyarakat yang tinggi terjadi dikawasan kelurahan ini. Kegiatan ini dilakukan dengan jumlah peserta yang terbatas bertujuan untuk mengurangi kerumanan masyarakat serta mencegah penyebaraan virus Covid-19. Selain itu, pembatasan jumlah peserta ini dilakukan atas dasar Peraturan Daerah yang ada.

Kegiatan pengabdian masyarakat di kelurahan Talia berjalan dengan lancar dan tertib serta mengikuti protokol kesehatan seperti memakai masker, menjaga jarak dan mencucui tangan. Materi yang disampaikan dalam kegiatan ini adalah edukasi tentang cara 
pembuatan dan penggunaan hand sanitizer dan desinfektan (Gambar 1). Materi pertama disampaikan tentang cara pembuatan hand sanitizer dengan melalui pemutaran video rekaman. Pembuatan video rekaman pembuatan hand sanitizer dilakukan di Laboratorium Kimia Farmasi STIKES Mandala Waluya Kendari. Video ini dibuat agar masyarakat dapat mudah untuk memahami tahapan-tahapan pembuatan hand sanitizer dan desinfektan. Pemutaran video dilakukan dengan panduan dari pembawa materi kegiatan untuk menjelaskan kepada masyarakat jika ada hal-hal yang belum dipahami. Materi kedua yang disampaikan dalam kegiatan ini adalah cara penggunaan hand sanitizer dan desinfektan yang benar dan tepat sasaran. Materi ini disampaikan bertujuan untuk memberikan pemahaman kepada masyarakat agar memahami tata cara penggunaan, frekuensi pengguaan serta cara menyimpan hand sanitizer dan desinfektan yang benar.

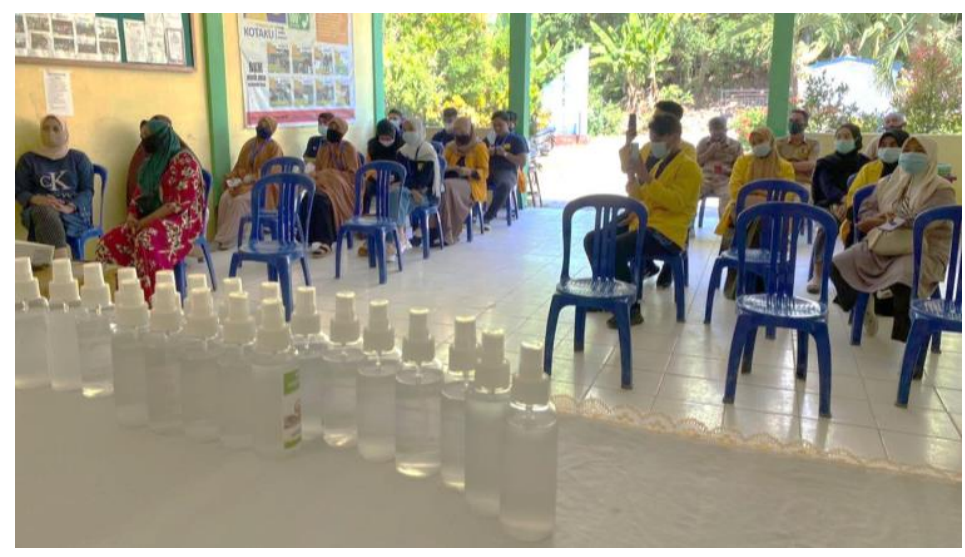

Gambar 1. Kegiatan penyuluhan penggunaan hand sanitizer dan desinfektan

Dalam kegiatan ini juga dilakukan proses tanya jawab dengan masyarakat terkait penggunaan hand sanitizer dan desinfektan serta tata cara mengurangi dan mencegah penyebaran virus COVID19 secara mandiri (Gambar 2). Masyarakat yang hadir sangat antusias dengan materi yang disampaikan dalam kegiatan ini dibuktikan dengan banyaknya pertanyaan yang diberikan kepada pemateri. Tahapan akhir dari kegiatan ini adalah dengan monitoring atau evaluasi untuk melihat tingkat pemahaman warga terkait materi yang diperoleh. Hasil yang diperoleh adalah baik, bahwa masyarakat memahami tahapan-tahapan pembuatan dan penggunaan hand sanitizer dan desinfektan.

Dalam kegiatan pengabdian masyarakat ini dilakukan pembagian produk hand sanitizer dan desinfektan kepada masyarakat dengan tujuan memberikan motivasi pada masyarakat untuk membuat secara mandiri produk tersebut dirumah. Selain itu, masyarakat juga diberikan soft file dalam bentuk 
flash disk yang berisikan video cara desinfektan sederhana dirumah pembuatan hand sanitizer dan

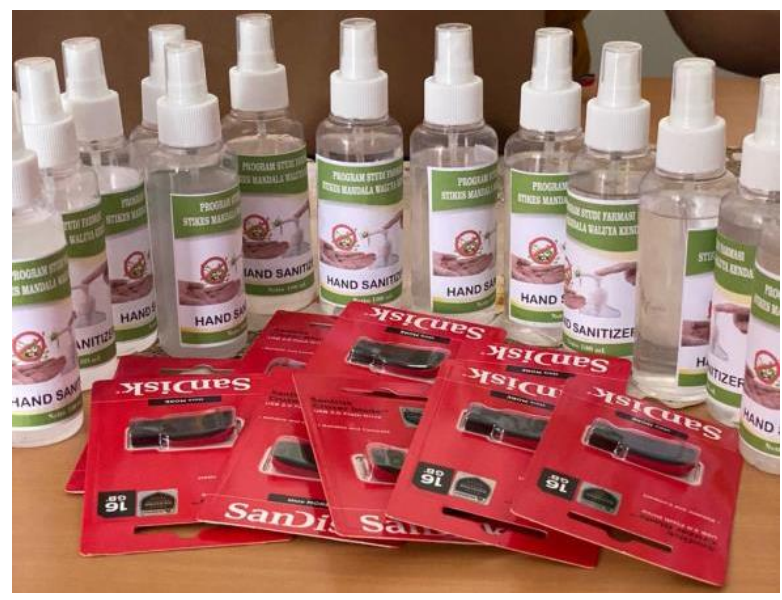

Gambar 2. Produk hand sanitizer dan soft file video cara pembuatan hand sanitizer dan desinfektan

Kegiatan pengabdian masyarakat ini merupakan salah satu upaya dalam mencegah penyebaran rantai penyebaran virus Covid-19 di Kota Kendari. Hal ini berkaitan dengan perilaku serta pemahaman masyarakat terhadap tindakan pencegahan salah satunya penggunaan hand sanitizer dan desinfektan. Pemahaman tentang tindakan pencegahan ini perlu dimengerti oleh masyarakt agar jumlah pasien yang terinfeksi virus Covid-19 tidak bertambah. Upaya minimal yang dapat dilakukan oleh masyarakat adalah menerapkan protokol kesehatan dirumah masing-masing. Protokol kesehatan yang dimaksud bukan sekedar semboyan $3 \mathrm{M}$ (Memakai masker, Mencuci tangan, Menjaga jarak). Tetapi dengan pemanfaat hand sanitizer dan desinfektan merupakan tambahan prosedur yang dapat digunakan oleh masyarakat dalam upaya pencegahan penyebaran virus Covid-19.

\section{KESIMPULAN}

Kegiatan pengabdian masyarakat di Di Wilayah Desa Talia Kecamatan Abeli Kota Kendari didukung dengan sangat baik oleh warga. Kegiatan penyuluhan dan diskusi dengan masyarakat telah dilaksanakan. Hasil dari kegiatan ini adalah meningkatnya pemahaman masyarakat tentang pembuatan dan penggunaan hand sanitizer dan desinfektan

\section{UCAPAN TERIMA KASIH}

Penulis mengucapkan ucapan terima kasih STIKES Mandala Waluya Kendari yang menjadi sumber dana sehingga kegiatan ini dapat terlaksana.

\section{DAFTAR PUSTAKA}

Susilo, A., Rumende, C.M., Pitoyo, C.W., Santoso, W.D., Yulianti, M., Herikurniawan, H., Sinto, R., Singh, G., Nainggolan, L., Nelwan, E.J. and Chen, L.K., 2020. Coronavirus Disease 2019: Tinjauan Literatur Terkini. Jurnal 
Penyakit Dalam Indonesia, 7(1), pp.45-67.

Fadli, A., 2020. Mengenal covid-19 dan cegah penyebarannya dengan "peduli lindungi" aplikasi berbasis andorid.

Juaningsih, I.N., Consuello, Y., Tarmidzi, A. and NurIrfan, D., 2020. Optimalisasi Kebijakan Pemerintah dalam penanganan Covid-19 terhadap Masyarakat Indonesia. SALAM: Jurnal Sosial dan Budaya Syar-i, 7(6), pp.509518.

Astuti, S.F., Nursyabania, L., Falih, M.J., Attamini, S.R., Rafli, M. and Musta'ina, S., 2020. Sosialisasi Adaptasi Kebiasaan Baru Di Rt 5/Rw 11, Kelurahan Kalisari, Kecamatan Pasar Rebo, Jakarta Timur Menghadapi Pandemi Covid-19. Jurnal Layanan Masyarakat (Journal of Public Services), 4(2), pp.448-455. 